Kiselyov Y. O., Adamenko M. I., Rudy R. M. Conceptual fundamentals of ecological tourism development in Ukraine. Journal of Education, Health and Sport. 2020;10(8):298-307. eISSN 2391-8306. DOI http://dx.doi.org/10.12775/JEHS.2020.10.08.035 https://apcz.umk.pl/czasopisma/index.php/JEHS/article/view/JEHS.2020.10.08.035

https://zenodo.org/record/3994957

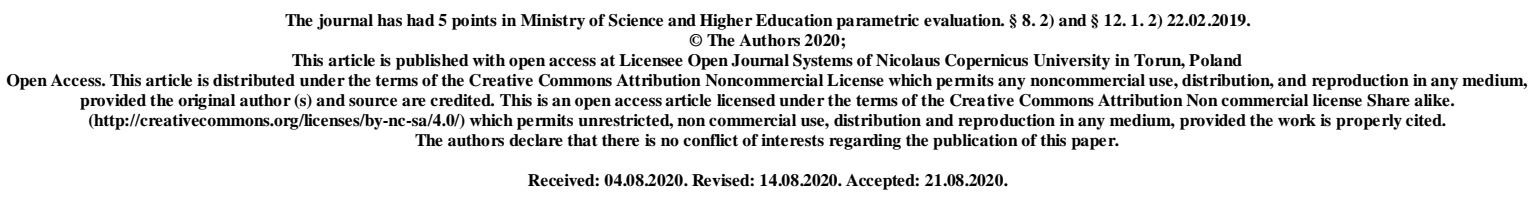

УДК 338.48-6:502/504

\title{
CONCEPTUAL FUNDAMENTALS OF ECOLOGICAL TOURISM DEVELOPMENT IN UKRAINE
}

Y. O. Kiselyov, Doctor of Geographical Sciences, Professor, Head of the Department of Geodesy, Cartography and Cadastre of Uman National University of Horticulture,

M. I. Adamenko, Doctor of Technical Sciences, Professor of the Department of Ecology and Life Safety of Uman National University of Horticulture,

R. M. Rudy, Doctor of Technical Sciences, Professor of the Department of Geodesy, Cartography and Cadastre of Uman National University of Horticulture

\section{Abstract}

The article covers elaborating the conceptual framework of the development of ecological tourism. The work expounds the notion and principles of ecotourism adopted in accordance with international agreements, and evolves the criteria of an ecotourism offer. The proposed wording of the modern concept of ecotourism implies ecological educating the participants of ecotourism activities and local residents and is aimed at attaining the socioeconomic objectives on condition that the natural and cultural heritage is preserved for future generations. The national experience and the features of developing ecotourism in Belarus are analyzed, including the analysis of ecotourism in protected areas, agritourism, and greenways. The most significant socio-economic aspects of the growth of ecological tourism are produced.

Key words: tourism; ecotourism; nature reserve fund; national nature park; potential. 


\section{КОНЦЕПТУАЛЬНІ ОСНОВИ РОЗВИТКУ ЕКОЛОГІЧНОГО ТУРИЗМУ В УКРАЇНI}

Ю. О. Кисельов, доктор географічних наук, професор, завідувач кафедри геодезії, картографії i кадастру Уманського національного університету садівництва,

М. I. Адаменко, доктор технічних наук, професор кафедри екології та безпеки життєдіяльності Уманського національного університету садівництва,

Р. М. Рудий, доктор технічних наук, професор кафедри геодезії, картографії і кадастру Уманського національного університету садівництва

Анотація
Стаття присвячена розвитку концептуальних основ розвитку екологічного туризму. В роботі окреслено поняття і принципи екологічного туризму, прийнятих відповідно до міжнародних угод, виділені критерії екотуристичного продукту. Сформульована сучасна концепція екотуризму, що передбачає екологічну освіту та виховання учасників екотуризму та населення, спрямованих на досягнення соціальноекономічних цілей, за умови, що для майбутніх поколінь зберігається природна i культурна спадщина. Проаналізовано національний досвід та особливості розвитку екотуризму в Україні в таких формах, як екотуризм в спеціально захищених природних зонах, агро-екотуризм та зелений туризм. Окреслено найбільш значущі соціальноекономічні аспекти розвитку екологічного туризму.

Ключові слова: туризм; екотуризм; природно-заповідний фонд; національний природний парк; потенціал.

Formulation of the problem. Due to the widespread implementation of the international concept of sustainable development, the role of eco-tourism is growing, according to the World Tourism Organization, the annual growth of the ecotourism segment since the early 1990s from 20 to $30 \%$, while global tourism growth is about $4 \%$. In different countries and regions, tourism is becoming an important industry and has an impact on the development of other sectors of the economy.

The Government has approved the Strategy for the Development of Tourism and Resorts until 2026. The document is designed to create conditions for accelerated development of tourism and resorts, turning it into a highly efficient, integrated into the world 
market industry. Implementation of the Strategy is envisaged in the following areas, including: ensuring the safety of tourists and protecting their legal rights and interests, implementation of EU legislation in the field of tourism, ensuring integrated development of territories, including creating favorable conditions for attracting investment in tourism infrastructure. tourism, formation and promotion of a positive image of Ukraine as a country attractive for tourism. Implementation of the act is envisaged at the expense of state, local budgets and other sources not prohibited by law, and the amount of funding will be determined annually, taking into account specific tasks and real opportunities.

Due to the prospects for the development of ecotourism in Ukraine, there is interest in interpreting the modern concept of ecotourism, its principles and criteria that must meet the eco-tourism product, as well as the study of socio-economic aspects of eco-tourism.

The scientific novelty of the study is to develop and refine theoretical and practical provisions for the development and regulation of economic and social processes in the field of ecotourism, taking into account the specifics of the market of tourist services and the peculiarities of territorial development.

Analysis of recent research and publications. In Ukraine, there are natural areas that have been little changed by human activities, so ecotourism with a responsible attitude to nature and with the least impact on the environment has prospects for development. This type of tourism contributes to the sustainable development of territories, involves the participation of local people in the provision of services, creates economic incentives for environmental protection.

Scientific issues of ecological tourism development as a promising type of tourist activity are covered in the works of domestic and foreign scientists, such as: E. Arsenyeva, O. Beidyk, V. Hetman, V. Yermachenko, O. Zima, A. Kuskova, O. Lyubitseva, S Melnychenko, L. Obolentseva, J. Oliynyk, V. Petronivsky, I. Rusev, M. Rutynsky, T. Sergeeva, L. Tranchenko, V. Khrabovchenko, V. Yavorska.

The purpose of this study is to develop and clarify the conceptual provisions for the development of ecotourism and identify its impact on the socio-economic status of society.

Presentation of the main research material. The first definition of ecotourism was given in 1983 by Mexican environmental economist Ceballos-Lascurain. In 1996, the International Conservation Organization adopted the following definition: ecotourism is an environmentally responsible journey through relatively unrelated natural areas, the study of nature and cultural monuments that contribute to the preservation of the environment, cause minimal damage to nature and create socio-economic benefits for local people. 
Later, various authors and organizations interested in the development of ecotourism proposed other definitions, based on which the distinctive features of ecotourism were formulated: acquaintance with the animal world and local customs and culture [1]; prevention of negative impact on nature and culture [2]; minimization of negative environmental and sociocultural impacts and maintenance of environmental sustainability [3]; promoting the protection of nature, natural resources and the local socio-cultural environment [4]; environmental education and training [5]; participation of local residents and their income from tourism [6]; economic efficiency and ensuring the socio-economic development of territories [7].

In 1996, the basic principles of the ecotourism philosophy were identified for the tourism industry, including promoting the conservation, protection and restoration of ecosystems, participation in the tourism process of local people, and support for the culture and interests of indigenous communities.

The primary goal in the development and development of the concept of ecotourism belongs to international organizations. Ecotourism is the subject of a number of important official international declarations. These include the Berlin Declaration on Biodiversity and Sustainable Tourism (1997), the Global Code of Tourism Ethics (1999), the Quebec Declaration on Ecotourism (2002) and a number of other international instruments [3].

The Quebec Declaration separated the concept of "ecotourism" from the more general concept of "sustainable tourism" by a number of criteria that must meet the eco-tourism product. It is political and financial support for environmental protection, recognition and respect for the rights of local and indigenous communities, as well as cultural and environmental education of tourists.

The above principles and criteria reveal the essence of ecotourism and allow to refer to ecotourism only those trips, the direct result of which is the improvement of ecological, socioeconomic condition of the visited regions.

The modern concept of ecotourism is a complex concept of ecological management, which provides ecological education and upbringing of ecotourists and the population, aimed at achieving socio-economic goals, provided that for future generations the natural and cultural heritage is preserved.

The modern concept of ecotourism is revealed not only in its principles, but also in the criteria of tourism ecology [8]:

$\square$ compliance with the maximum allowable norms of anthropogenic (recreational) load;

$\square$ environmentally friendly transport is used;

$\square$ compliance with established rules of conduct in natural areas; 
certification of ecological routes and services in accordance with international requirements;

$\square$ use of environmentally friendly materials, conservation of natural resources.

Together with the concept of ecotourism, the image of a modern ecotourist is formed - a person striving for self-improvement, self-development, knowledge and gaining new experience, a traveler who wants to make a personal contribution to the environment and respects the interests of local people. ready to adapt to the local way of life.

Due to a number of environmental, economic, social and political considerations, ecotourism is growing rapidly today through the implementation of global, national, regional and local ecotourism strategies. The greatest demand for ecotourism exists in North America, Western Europe (Germany and the United Kingdom) and Australia. In some countries, the demand for ecotourism in the domestic market is also important (for example, Thailand, Indonesia).

In Ukraine, the popularity of ecotourism began with the creation of the Ukrainian Association of Active and Ecological Tourism. The Ukrainian Association of Active and Ecological Tourism is a public initiative that promotes and develops nature-friendly active recreation and ecological tourism. Association - a field of professionals where they exchange relevant information, raise and solve pressing problems. Promote a healthy lifestyle and a harmonious relationship between Man and Nature.

The main activities of state institutions of Ukraine in the field of ecotourism are to promote the concept of ecological tourism in Ukraine, support international cooperation in ecotourism, promotion of eco-services in the national and international tourism market, training in ecotourism, support for traditional Ukrainian crafts and crafts.

At present, a number of forms of ecotourism organization have been formed in Ukraine. One of the main ones is ecotourism in natural areas, which is developing in the following areas: ecological educational tours, photo hunting for rare animals and birds in the wild, the organization of tourist trips to protected areas, tours of aquatic ecosystems and more.

In Ukraine, there are areas suitable for the development of ecotourism in its classical sense, ie areas where human-modified landscapes and local ethnocultural features are combined. The most interesting for ecotourism is the Carpathian region, where among the mountains and forests, in the valleys of mountain rivers for centuries retain their unique traditions of Hutsuls, Boyks, Lemkos. Much of the land in the region belongs to the nature reserve fund of Ukraine. The Carpathian region still has unique types of wooden construction, especially churches, Hutsul music and dances, original folk clothing, rich museum collections 
of antiquities, unique Hutsul crafts - carving, metalworking, wool products, which indicates a high level of skill. Hutsuls. There are always ethnic festivals, traditional holidays that will touch the rich culture of the Carpathian ethnic groups. However, not only the Carpathians provide opportunities for the development of ecotourism in Western Ukraine. Podillya is a unique region. Podilsky Tovtry National Nature Park, a nominee of the Seven Wonders of Ukraine competition, has unique natural features, a large number of historical, cultural and archeological monuments [9].

The northern regions of Ukraine also have a unique nature. The territory of Polissya is a large forest massif, a dense network of rivers, lakes and swamps. The region has well preserved its natural resources and ethnocultural heritage. Polissya has all the necessary prerequisites for the development of ecotourism: the presence of nature reserves, the diversity of the region's landscapes, the rich species composition of flora and fauna, the presence of unique architectural, archaeological and cultural monuments, original folk crafts (eg boarding).

The Black Sea coast has many protected areas, where unique landscapes and nesting places of rare bird species are protected. The most interesting object of ecotourism is the village of Vilkove, surrounded by the territory of the Danube Biosphere Reserve, which is called "Ukrainian Venice" due to its location at the mouth of the Danube. The village is truly unique, as it preserves rare housing in Europe - instead of streets there is a system of canals, and boats are used for transport.

The steppe regions of Ukraine have significant potential for the development of ecotourism. Mykolaiv, Zaporizhia, Kherson, and Donetsk regions have objects of the nature reserve fund, where the unique steppe flora has been preserved. Here are the Ukrainian steppe nature reserve "Yelanetsky steppe", biosphere reserve "Askania-Nova". An interesting object of ecotourism in the Kherson region is the area of Oleshkiv Sands, which is considered to be the largest sand massif in Europe. In the Donetsk region, on the banks of the Seversky Donets River, there is the Holy Mountains National Nature Park, which has the status of a protected area due to its unique natural landscapes, rare plant species and the historical significance of this area. In Mykolayiv region, in the valley of the Southern Bug River, there is the Bug Nature National Park. Nature here is little changed by man, the species composition of flora and fauna is unique, and the exits to the surface of the granites give the plain Bug the appearance of a fast and stormy mountain river. The Buzhsky Gard tract, which is part of the park, is a monument to the historical landscape of the liberties of the Zaporozhian Sich, the first Cossack republic. 
The strategy of sustainable development of ecological tourism in Ukraine is developed, provides a comprehensive assessment of resource potential; environmental, socioeconomic, regulatory and information support for sustainable development and environmental management; introduction of innovative environmentally friendly technologies.

In general, there is a positive trend in the development of ecotourism in natural areas of Ukraine, where the flow of ecotourists increases every year, various tourism programs are created, environmental and educational work is carried out, and infrastructure is gradually rebuilt. At the same time, we must continue to work on the environmental regulation of tourism and pay attention to increasing the involvement of local people in the tourism business.

Agroecotourism - an actively developed form of ecotourism in Ukraine has a number of prerequisites for the development of rural tourism. In world practice, agro-ecotourism has been isolated in a separate sector since 1972 and brings significant economic benefits to countries: for example, annual income from rural tourism in Italy reaches $\$ 350$ billion, and in Switzerland tourism revenue is only $\$ 15$ billion. per year, and 10 billion dollars. give farmers in mountainous areas.

Among the favorable conditions for the development of agro-ecotourism in rural Ukraine should be the following: picturesque natural landscapes; a large number of monuments of archeology, history and culture, nature; original traditions and customs, crafts and handicrafts, folklore and at the same time the presence of unprofitable agricultural organizations, low wages of rural residents.

Relatively young forms of ecotourism development in the world are green routes multifunctional routes for travel on them by non-motor vehicles operating along natural corridors, historical trade routes, rivers and railways. The concept of green routes originated in the 1950s in the United States, where today there are more than 18,000 thousand. $\mathrm{km}$. and there are hundreds of NGOs involved in the development of this idea.

The experience of foreign countries shows that the development of ecotourism can have a wide range of consequences for society at the local, regional and national levels, from favorable to destructive. At each of these levels, the economic, environmental and social impacts of tourism can vary significantly depending on the size, level of development and diversification of the local economy, the cultural characteristics of the country or region. In addition, the form of ecotourism developing in the region is important. In this regard, we will consider important socio-economic aspects related to the development of ecotourism, examples of both positive and negative impacts: 
1. Impact on the economy of the country and individual territories. Tourism is a highly profitable industry, contributes to the diversification of the economy and increase the inflow of foreign currency into the country. Tourism stimulates the development of other industries and activities - agriculture, light industry, building materials, hotel and transport services, trade and food. At the same time, tourism is an unstable source of income, influenced by many factors, strong fluctuations in demand, seasonality, economic and political crises.

2. Impact on the social sphere (job creation and welfare). Thus, it directly and indirectly affects the creation of jobs and incomes. tourism contributes to the development of modern infrastructure, which is used not only by tourists but also by locals. tourism has a high opportunity to create jobs, but creates mostly unskilled, seasonal, low-paid jobs.

3. Impact on the cultural sphere. the development of tourism can serve to strengthen traditional culture, strengthen the cultural identity of the local population. Positive socioeconomic functions of ecotourism development are: stimulating the production of environmentally friendly products; inflow of investments in nature, infrastructure and services; development of special ecologically-oriented education in the field of tourism and ecological management.

Conclusion. Thus, the modern concept of ecotourism emphasizes the obligation to promote the preservation of natural and cultural heritage, biodiversity and improve the ecological, socio-economic status of the regions visited by ecotourists. Eco-tourism should become a model for reorganization, greening of the entire tourism industry. Sustainable ecologically balanced tourism should become not only a philosophy, but also a leading management strategy for tourism development in the region.

\section{Список використаних джерел}

1. Шумлянська Н. В. Екотуризм як форма долучення до природної та культурної спадщини [Електронний ресурс] / Н. В. Шумлянська // Культура України. - 2014. Вип. 47. - Режим доступу : http://www.ic.ac.kharkov.ua/RIO/kultura47/15.pdf

2. Еко і сільський туризм: точки перетину [Електронний ресурс]. - Режим доступу : https://mykrai.wordpress.com

3. Українська асоціація активного та екологічного туризму [Електронний ресурс]. - Режим доступу : http://uaeta.org/ua/tourism/17 Вісник ТНЕУ № 1, 2016 p. 41

4. Білецька Г. А. Розвиток екотуризму як засіб економічного зростання Хмельницької області / Г. А. Білецька // Вісник Хмельницького національного університету. - 2010. - №10. - Т. 2. - С. 245-247.

5. Луцька Н. I. Маркетингова інноваційна стратегія розвитку туристичного 
бізнесу. Інвестиції: практика та досвід / Н. І. Луцька, І. З. Криховський. - 2009. - №6. C. $27-30$.

6. Богуш Л. Г. Екотуризм як вектор інтеграції соціально-економічної та екологічної складових сталого розвитку [Електронний ресурс] / Л. Г. Богуш. - Режим доступу : http://economics-of-nature.net/uploads/arhiv/2008/Bogush.pdf

7. Рунців О. І. Проблеми розвитку екологічного туризму в Україні // Вісник наукових досліджень. - 2006. - Вип. 1. - С. 180-183. - (Серія «Туризм»).

8. Блакберн А. А. Региональные ландшафтные парки как туристскорекреационные предприятия в контексте устойчивого развития туризма в Украине / А. А. Блакберн // Вісник ДІТБ. - 2005. - №9. - С. 190-196. - (Серія «Економіка, організація і управління підприємствами в туристичній сфері»).

9. Ерчак О. В. Формирование условий для развития экотуризма на особо охраняемых природных территориях / О. В. Ерчак // Эколого-экономический механизм сохранения биоразнообразия особо охраняемых природных территорий. - Брест : Альтернатива, 2007. - С. 221-222.

10. Транченко Л. В. Туризм як пріоритетний напрям розвитку сільської економіки / Л. В. Транченко // Науковий економічний журнал «Актуальні проблеми економіки». 2015. - № 9. - C. 162-168.

\section{References}

1. Shumlanska N. V. Ecotourism as a form of attachment to the natural and cultural heritage / N.V.Shumlanska // Culture Of Ukraine. - 2014. - № 47. [Electronic resource]. Access mode: http://www.ic.ac.kharkov.ua /RIO/kultura47/15.pdf

2. Eco and rural tourism: point of intersection [Electronic resource]. - Access mode : https://mykrai.wordpress.com

3. Ukrainian Association of active and eco-tourism [Electronic resource]. - Access mode : http://uaeta.org/ua/tourism/17

4. Biletska G. A. Development of ecotourism as a means to economic growth of Khmelnitsky region / G. A. Biletska // Bulletin of the Khmelnytsky National University. 2010. - № 10. - T. 2. - P. 245-247.

5. Lutska N. I. Marketing innovation strategy of development of tourist business. Investments: practice andexperience/ N. I. Lutska, I. Z. Kryxovsky. -2009. - №6. -P. 27-30.

6. Bogush L. G. Ecotourism as a vector of integration of socio-economic and environmental components of sustainable development [Electronic resource] / L. G. Bogush. - Access mode : http://economics-of-nature.net/uploads/arhiv/2008/Bogush.pdf 
7. Ryntziv O. I. Problems of development of ecological tourism in Ukraine // Bulletin of scientific research. Ser.: Tourism / Halych Institute. V. Chornovil. - Ternopil, 2006. - № 1. P. 180-183.

8. Blackbourne A. A. Regional landscape parks as tourist-and-recreational businesses in the context of sustainable development of tourism in Ukraine / A. A. Blackbourne // Bulletin DMTB : Economics, organization and management of enterprises in the tourism sector.2005. - № 9. - P. 190-196.

9. Erchak O. V. Formation of conditions for the development of ecotourism on specially protected natural territories / O. V. Erchak // the ecological and economic mechanism of conservation of biodiversity of especially protected natural territories-Brest : Alternative, 2007. - P. 221-222.

10. Tranchenko L. Tourism as priority direction of rural economy development / L. Tranchenko // Scientific economic journal «Actual problems of economy». - 2015. - № 9. - P. 162168. 